\title{
Integrating UDL Strategies Into the Online Course Development Process: Instructional Designers' Perspectives
}

\author{
Korey Singleton, Anya Evmenova, Marci Kinas Jerome, and Kevin Clark \\ George Mason University
}

\begin{abstract}
This qualitative case study design examined the perspectives that instructional designers at a fouryear research institution in the Mid-Atlantic region of the United States have about integrating UDL strategies into the online course development process. The participants were six individuals involved in the online course development process: four of the participants were instructional designers working for the Instructional Design Team, one participant was an assistant program manager in the Office of Distance Education, and the other was an instructional designer working in the College of Health and Human Services. The interviews focused on the participant's perspectives on the integration of UDL strategies and how they believe faculty perceived such practices. Using a series of semistructured interviews and document analysis, three distinct themes emerged: (a) the importance of the instructional designer-faculty member partnership, (b) the number of factors impacting faculty adoption of UDL strategies in their online courses, and (c) faculty resistance to changes in how classroom accommodations are addressed in the higher education classroom. In addition to highlighting factors impacting the integration of UDL strategies, the findings also revealed techniques that could be useful in improving faculty adoption of such practices.
\end{abstract}

Keywords: online learning, accessibility, UDL, universal design, disability, distance education, higher education, online course development, instructional design

Singleton, K., Evmenova, A., Kinas Jerome, M., \& Clark, K. (2019). Integrating UDL strategies into the online course development process: Instructional designers' perspectives. Online Learning, 23(1), 206-235. doi:10.24059/olj.v23i1.1407

\section{Integrating UDL Strategies Into the Online Course Development Process: Instructional Designers' Perspectives}

Disability support services (DSS) in higher education is situated in the "medical model" as it relates to supporting students with disabilities (Burgstahler, 2012). In other words, a student with a disability (SWD) must register with the DSS office and provide medical documentation supporting their disability before classroom accommodations (e.g., extended time on exams/quizzes) are authorized. Unfortunately, research shows faculty members are often confused about their role in the accommodations process (Burgstahler, 2007; Izzo, Murray, \& Novak, 2008; Silver, Bourke, \& Strehorn, 1998) and that many accommodations require faculty members to 
retrofit or modify existing instructional materials (Aguirre \& Duncan, 2013; Izzo et al., 2008; Kumar, 2010) to ensure equivalent access.

To address this issue, many disability services professionals have touted inclusive teaching pedagogies like Universal Design for Learning, or UDL, as a viable strategy for improving access to instructional resources for SWDs (Dallas, Upton, \& Sprong, 2014; Higbee \& Goff, 2008). UDL was developed by the Center for Applied Special Technologies (CAST) in the 1990s (CAST, 2011). It is a set of guidelines that encourage instructors to create a flexible, equitable learning curriculum that meets the needs of a diverse body of learners without the need for customization or retrofitting. In recent years, the perceived benefits attached to implementing UDL principles and practices in the higher education classroom (face-to-face, hybrid, and/or online) to support SWDs, particularly those with learning disabilities and other cognitive impairments (e.g., ADD/ADHD, psychological), are clearly documented (Burgstahler, 2011; Gradel \& Edson, 2009; McGuire \& Scott, 2006; McGuire, Scott, \& Shaw, 2003). Additionally, the research supports that UDL interventions are positively perceived by both instructional faculty (Catalano, 2014; Grabinger, Aplin, \& Ponnappa-Brenner, 2008; Habib et al., 2012; Rao \& Tanners, 2011; Seok, DaCosta, Kinsell, \& Tung, 2010) and students (Baker, Cimini, \& Cleveland, 2011; Habib et al., 2012; Rao \& Tanners, 2011; Schelly, Davies, \& Spooner, 2011; Seok et al., 2010; Simoncelli \& Hinson, 2008; Vajoczki et al., 2014; Yang, Tzuo, \& Komara, 2011). Despite this growing body of evidence, instructional faculty have still been slow to adopt UDL.

To date, we have identified only one study examining the underlying issues impacting the adoption of UDL strategies by instructional faculty (Moriarty, 2007). More research is needed to address this gap. This paper highlights a qualitative case study design examining the perspectives that instructional designers (IDs) at a 4-year research institution in the Mid-Atlantic region of the United States have about integrating UDL strategies into the online course development process. At this institution, IDs are a critical part of the online course development process, guiding and supporting faculty through each phase of this process. As such, they play a pivotal role in the integration of UDL strategies. This study seeks to offer insight into the experience of IDs when it comes to integrating these strategies into the online course development process.

\section{Review of Related Literature}

In the following sections, we will discuss universal design versus the medical model and the relevant literature surrounding the integration of UDL strategies by instructional faculty in higher education. Additionally, we will highlight existing online course development practices at the institution.

\section{Universal Design Versus the Medical Model}

The success of the medical model relies heavily on the student disclosing that they have a disability and require accommodations to support their needs in the classroom. Without that disclosure, it is likely many SWDs will not have what they need. This is where UDL comes in. UDL originates from the term Universal Design (UD), which is defined as "the design of products to the greatest extent possible by people of all ages and abilities, without the need for customization or specialized design" (Burgstahler, 2012). UD was conceived by a group of architects, engineers, and environmental designers at North Carolina State University's Center for Universal Design (CUD) in 1997 and is built on seven core principles: (1) equitable use, (2) flexibility in use, (3) simple and intuitive use, (4) perceptible information, (5) tolerance for error, (6) low physical effort, and (7) size and space for approach and use ("The Center for Universal Design - Universal Design 
Principles," n.d.). An example of UD in the physical environment would be curb cuts or automatic doors. While certainly beneficial to individuals with physical impairments (e.g., those who use a wheelchair), these adaptations are also helpful to individuals pushing strollers or those with issues negotiating obstacles like stairs or heavy doors. Many curb cuts also incorporate yellow markings and textured surfaces to make them easier for individuals with visual impairments to identify.

UDL was first introduced by CAST in 1998 with the goal of extending the principles of UD into the educational space. UDL consists of three core components: (1) multiple means of engagement, to tap into learner's interests, offer appropriate challenges, and increase motivation; (2) multiple means of representation, to give diverse learners options for acquiring information and knowledge; and (3) multiple means of action and expression, to provide learners with options for demonstrating what they know (Rose \& Gravel, 2012). It is built around the idea that universally designed curricula make it possible for students to have full access to course content despite physical limitations, learning disabilities, behavioral problems, or language barriers (Chodock \& Dolinger, 2009). Examples of UDL in the online environment could include the use of simple things like a Welcome/Start page and/or a brief video orienting learners to how best to navigate the online course. Other examples include captions and transcripts for videos or accessible documents that ensure all learners have equal access to course materials. These are some of the reasons that UDL is widely viewed as an attractive pedagogy for supporting the broad educational needs of postsecondary SWDs.

\section{Additional Universal Design in Education Models}

Unlike UDL, which encourages flexibility in the design of instruction, researchers intended Universal Instructional Design (UID) and Universal Design for Instruction (UDI) to offer faculty members a structured plan with respect to designing inclusive classroom instruction. The thought was that this more prescriptive approach would improve the likelihood that these practices could be adopted on a larger scale by postsecondary education faculty. UID incorporates many of the common instructional accommodations that SWDs request from faculty members (e.g., extended time, copies of lecture notes, etc.) into the overall instructional design for the course (Silver et al., 1998). It was thought that this would eliminate the need for these students to have to request services from the disability support service office because those supports would already be built into the instruction.

McGuire, Scott, and Shaw (2003) developed UDI by adapting UD specifically to promote inclusive teaching practices by faculty in postsecondary education. They use the same seven principles as in UD (i.e., flexibility in use, low physical effort, etc.), but adjusted the definitions to focus on instruction and added two additional principles: (8) a community of learners and (9) instructional climate (see Table 1). While the initial seven principles focus more on the flexibility and design of the instruction, these last two principles ensure that the students remain engaged in the classroom. 
Table 1

The Nine Principles of Universal Design for Instruction

\section{Principle}

Principle 1: Equitable use

Principle 2: Flexibility in use

Principle 3: Simple and intuitive

Principle 4: Perceptible information

Principle 5: Tolerance for error

Principle 6: Low physical effort

Principle 7: Size and space for approach and use

Principle 8: A community of learners

Principle 9: Instructional climate

\section{Definition}

Instruction is designed to be useful to and accessible by people with diverse abilities. Provide the same means of use for all students; identical whenever possible, equivalent when not.

Instruction is designed to accommodate a wide range of individual abilities. Provide choice in methods of use.

Instruction is designed in a straightforward and predictable manner, regardless of the student's experience, knowledge, language skills, or current concentration level. Eliminate unnecessary complexity.

Instruction is designed so that necessary information is communicated effectively to the student, regardless of ambient conditions or the student's sensory abilities.

Instruction anticipates variation in individual student learning pace and prerequisite skills.

Instruction is designed to minimize nonessential physical effort in order to allow maximum attention to learning. Note: This principle does not apply when physical effort is integral to essential requirements of a course.

Instruction is designed with consideration for appropriate size and space for approach, reach, manipulations, and use regardless of a student's body size, posture, mobility, and communication needs.

The instructional environment promotes interaction and communication among students and between students and faculty.

Instruction is designed to be welcoming and inclusive. High expectations are espoused for all students.

Note. Adapted from "Universal Design for Instruction: The Paradigm, Its Principles, and Products for Enhancing Instructional Access," by J. M. McGuire, S. S. Scott, and S. F. Shaw, 2003, Journal of Postsecondary Education and Disability, 17, p. 13. Copyright 2003 by Journal of Postsecondary Education and Disability. 
Due to their emphasis on flexible design and broadly addressing the needs of all learners, UID, UDI, and UDL are often used interchangeably. While some studies have leaned on the additional flexibility of UDL (Bongey, Cizadlo, \& Kalnbach, 2010; Kumar \& Wideman, 2014; Smith, 2012), which incorporates only three core principles, others have taken a more prescriptive approach by utilizing either UID or UDI (Rao \& Tanners, 2011). To provide clarity going forward and eliminate any potential confusion, we will use the term $U D L$ or $U D L$ strategies. The term $U D L$ strategies can encompass many things and is sometimes used interchangeably with terms like accessible course design practices or inclusive design practices. Examples include providing videos with captions and/or transcripts, designing course documents (e.g., Word, PPT, and PDF) that are readable using assistive technology applications (e.g., text-to-speech software), providing alternatives for demonstrating competency (e.g., writing a paper vs. providing an oral presentation, etc.), scaffolding, and so on. UDL broadly captures the principles espoused by all three models, including accessible design, while offering greater flexibility in how an instructor meets the needs of diverse learners within their classroom.

\section{Implementing UDL in the Higher Education Classroom}

Whether it is done to support SWDs (Aguirre \& Duncan, 2013; Catalano, 2014; Dotger, 2011; Habib et al., 2012; Simoncelli \& Hinson, 2008), students who speak English as a second language (Ragpot, 2011), or simply to create a more inclusive classroom environment (Kumar, 2010; Nielsen, 2013), research shows that both faculty and students have positive attitudes with respect to the implementation of UDL in the higher education classroom. Unfortunately, this has not translated into the widespread adoption of UDL strategies by instructional faculty. In this literature review, we will examine faculty perceptions about implementing UDL, barriers impacting faculty adoption, and existing strategies to improve faculty adoption.

Faculty perceptions about implementing UDL in the classroom. Faculty members generally have positive perceptions with respect to implementing UDL or inclusive teaching practices. The issue lies, often, in awareness and defining exactly what UDL or "inclusive" teaching strategies actually mean. Using the Inclusive Teaching Strategies Instrument, or ITSI (Appendix A), Lombardi, Murray, and Gerdes (2011) evaluated both faculty members' perceptions and actions with respect to implementing UDL strategies in the classroom. Findings showed obvious discrepancies between what faculty members positively perceived about using UDL techniques and what they were actually doing with respect to implementing those strategies. In other words, faculty members were saying one thing and doing something completely different when it came to their courses.

Dallas et al. (2014) used three subscales (Multiple Means of Presentation, Inclusive Lecture Strategies, and Accommodations) within the ITSI to assess faculty perceptions (not actions) with respect to providing academic accommodations and using inclusive teaching strategies, as well as to determine if there were any differences between faculty groups. Findings showed that faculty members generally held positive attitudes toward providing academic accommodations. This is consistent with previous studies evaluating this issue (e.g., Baker et al., 2011; Dy, 2005; Hong \& Himmel, 2009; Rao, 2004). Additionally, they found statistically significant differences in their attitudes toward inclusive teaching practices on the Multiple Means of Presentation (MMP) scale for faculty who had more than 48 hours of prior disability-related training. This suggests that faculty members with disability-related training were more likely to incorporate inclusive design practices in their planning compared to those with no experience.

Barriers impacting faculty adoption of UDL. Only one study was identified that specifically evaluated faculty adoption of inclusive teaching practices. Moriarty (2007) carried out 
a multisite, mixed methods study evaluating the barriers to the adoption of inclusive teaching methods by science, technology, engineering, and math (STEM) faculty in a community college environment. Quantitative findings suggested a positive correlation between faculty adoption of inclusive teaching practices and their comfort with technology and pedagogical competencies. Additionally, faculty members indicated that a lack of time was a critical factor in their ability to adopt and learn new teaching methods/strategies. Qualitative findings largely supported the quantitative findings in that faculty members overwhelmingly indicated that high teaching loads and a lack of time to develop new teaching methods were the greatest barriers to inclusive pedagogy.

While no other studies focused specifically on faculty adoption, researchers did mention findings related to this issue. Similar to Moriarty (2007), other studies found that the amount of preparation time involved in creating accessible course materials (Kumar \& Wideman, 2014) and faculty members' limited knowledge with respect to teaching with technology (Aguirre \& Duncan, 2013; Nielsen, 2013; Ye, 2014) were cited as barriers. An additional factor to consider is the lack of faculty awareness with respect to supporting SWDs in their courses (Aguirre \& Duncan, 2013; Dotger, 2011; Habib et al., 2012; Kumar, 2010; Schelly et al., 2011). One could argue that if a faculty member were not aware that there is an issue with their current teaching practices, they would likely not consider implementing a new pedagogy. That is as much a barrier as those challenges that were previously identified.

Strategies for improving faculty adoption of UDL. To improve faculty adoption of UDL strategies, researchers have generally employed training interventions. Izzo, Murray, and Novak (2008) sought to measure faculty perceptions with respect to implementing UDL practices in the classroom to support SWDs. Using a web-based training module, faculty members learned about UDL and strategies for implementing such practices in the classroom. Pre- and posttest results suggested that the training was very well received, as the percentage of faculty members who reported having a moderate-to-high degree of UDL knowledge increased from $29 \%$ prior to the implementation of the training resource to approximately $94 \%$ after having participated in the training modules.

Likewise, UDL training interventions have proven effective in other studies as well. Both Davies et al. (2013) and Schelly et al. (2011) used students' feedback from pretests taken just 2-3 weeks into the semester to provide faculty members with focused UDL trainings (five total) over the course of the semester. As a result, posttest student responses indicated that they perceived that instructors implemented more UDL principles in the classroom after having participated in trainings. In particular, two major areas of instruction were impacted. First, instructors took more care to present concepts in multiple ways and provide course materials in multiple formats. Second, instructors spent more time summarizing key concepts before, during, and immediately after instruction. Thus, incorporating student feedback early in the course to aid in the course development process resulted in positive student outcomes.

These studies, while useful for evaluating the extent to which faculty members improved their knowledge with respect to implementing UDL strategies in the classroom, do have limitations, the most glaring being that there was no evidence that faculty members had chosen to incorporate that information into their teaching strategies in the semesters that followed. Although one longitudinal study attempted to address this by providing faculty participants with financial compensation (Moon, Utschig, Todd, \& Bozzorg, 2011), concerns were expressed as to whether the practices would continue after completion of the study. 


\section{Course Development Context and the Research Questions}

In this section, we discuss the basis for this research study and define the framework that will guide our inquiry. At the time of this study, two units played a critical role in the development and delivery of online courses and programs at the university: the DE Office, which is situated under the Provost's Office, and the Instructional Design (ID) Team, which is under the division of Information Technology Services (ITS). Some of the academic colleges and schools have faculty members and/or instructional designers playing a lead role in the development of online programs and services as well, but they focus primarily on their particular academic programs as opposed to the greater campus community. The DE Office partners with some of these programs, but still many others manage their online academic programs at the department level without support from the DE Office.

Existing course development models at the university. There are two predominant online course development models in place at the university: the 4-P process and the Online Course Development Institute (OCDI). Some faculty members and/or academic units design their own online courses without the support of the DE Office or the ID Team, but it is not clear what online course development model, if any, they are following.

4-P. The 4-P process for new DE course development was developed in 2010 by the DE Office and is a yearlong process of online course development consisting of four phases: (1) proposal, (2) production, (3) pilot, and (4) portfolio (Assistant Director of Distance Education, personal communication, September 25, 2015). Figure 1 details the process.

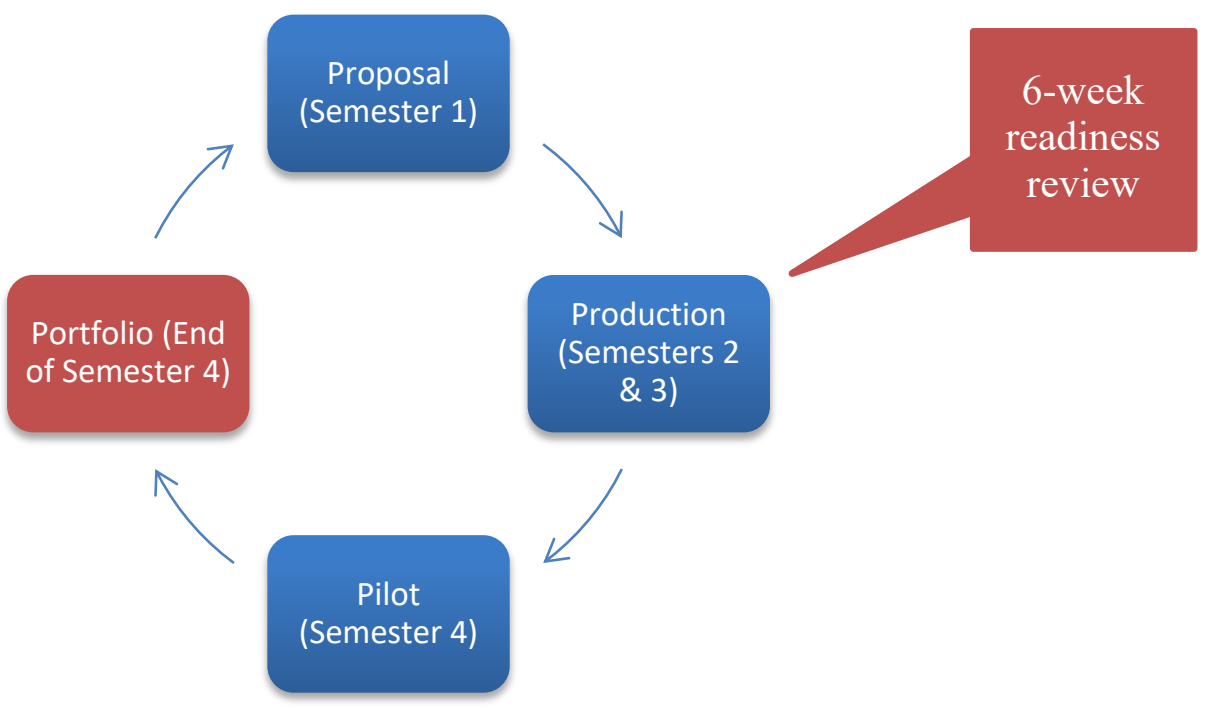

Figure 1. The 4-P process for new DE course development. Reprinted from Office of Distance Education, 2012.

The Provost's Office sends out a call for online proposals. Faculty members, with approval from their departments, submit proposals and, if accepted, are provided with a stipend for online course development and support from an ID throughout the yearlong process. Faculty members are provided with a great deal of support throughout all four phases of the development process.

During the production phase, faculty members receive guidance and resources from their IDs to aid them in the online course design and delivery process. As part of the course development 
process, the DE Office conducts a readiness review of the course (see Appendix C) six weeks prior to the start of the pilot phase, the first semester the course will be taught online (Assistant Director of Distance Education, personal communication, September 29, 2015). Faculty members receive the course readiness checklist prior to the review, and the IDs guide them through meeting the course and/or department-related requirements.

OCDI. As an alternative to the 4-P course development model, in spring 2015, LSS piloted the OCDI. OCDI is a web-based, 6-week asynchronous program, exemplifying best practices in instructional design and theory-based research (ID manager, personal communication, 2015). The target audience for the OCDI is tenured, tenure-track, adjunct, and term faculty members and graduate teaching assistants currently planning to design and develop online courses that will be taught at the university (Assistant Director of Distance Education, email communication, April 27, 2015). The program is facilitated by IDs from the ID team and utilizes a cohort-based model (departmental or interdisciplinary) with 10-15 participants per cohort. The final product of OCDI is a completed course module that will serve as the template for the rest of the online course modules (includes content, activities, assessments, etc.). There is no follow-up beyond completion of the cohort, but faculty members are free to meet individually with instructional designers for ad hoc support (Senior instructional designer, personal communication, October 6, 2015).

Issues impacting the online course development process. The online course development process across the university is not entirely consistent. In other words, there is not one set standard for how courses are developed and exactly what elements (e.g., template, learning objectives, syllabus, discussion, document structure, video platform, accessibility, etc.) are required for an online course. For example, faculty members developing courses with support from the DE Office (i.e., following the 4-P process) are required to undergo a thorough course readiness evaluation and receive ongoing training and guidance over the course of a year from IDs. Faculty members enrolled in the OCDI receive similar support from IDs; however, participation is voluntary. The training is conducted over a much shorter time frame (i.e., 6 weeks), and the focus of the OCDI is on building out one module that would act as a template for each of the other modules developed in the course. While both are effective in preparing faculty members to develop online courses, neither follows a similar set of standards when it comes to the course development process.

Faculty members developing courses outside the purview of the DE Office or the Learning Support Office (LSS) are not necessarily subject to any review process. Some may have college, department, or program-specific standards that they must meet, but those standards are likely not in line with what is required from the 4-P process or the OCDI.

Incorporating UDL strategies into the online course development process. According to 4-P process course portfolio review results from the fall of 2014 (Assistant Director of Distance Education, personal communication, September 25, 2015) and spring 2015 semesters (Assistant Director of Distance Education, personal communication, September 29, 2015), Item 12 (i.e., The course employs accessible technologies or strategies - e.g., alternative text, transcripts, closed captioning) scored the lowest (i.e., 3.48 and 3.24, respectively) of the 30 items measured on a fivepoint Likert scale. This indicates that faculty members are not incorporating UDL strategies (e.g., alternative text for meaningful images, captions/transcripts for video, etc.) in their courses. What is not clear is why this is happening. Item 3 (i.e., Syllabus and course schedule are thorough -including major components such as outcomes, assignments, readings, grading policy, due dates, etc.) scored roughly a point higher (4.42 and 4.26, respectively) and is described with equal nuance on the scoring sheet. However, course reviews are showing evidence that faculty members are 
more likely to include thorough course schedules and syllabi when developing their courses than they are UDL strategies.

An additional concern is that faculty members who develop courses outside of the purview of the DE Office and LSS do not receive the same types of faculty development support on the integration of UDL strategies as those who do. The DE Office piloted an "open call" process in spring 2015 for faculty members developing courses outside of the purview of their office. The idea was to introduce those faculty members to the office and the types of services and support available to them. A review of those courses revealed similar findings to those developed by the DE Office (IT accessibility specialist, personal communication, May 20, 2015). In other words, faculty members generally did not include UDL strategies in their online courses.

\section{Research Questions}

The following questions informed this research study:

1. What perspectives do online course developers (i.e., DE Office, ID team, IDs, and instructional faculty within colleges and schools) at the university have about incorporating UDL strategies into the online course development process?

2. How do online course developers and instructional faculty teaching online courses at the university define UDL strategies?

3. What factors do online course developers perceive as impacting the adoption or rejection of UDL strategies by instructional faculty teaching online courses at the university?

\section{Methods}

This study uses a qualitative case study design examining the perspectives that IDs at a four-year research institution in the Mid-Atlantic region of United States have about integrating UDL strategies into the online course development process to support SWDs. Johansson, in Ruddin (2006), stated that a case study is an in-depth study of the particular, where the researcher seeks to increase his or her understanding of the phenomena being studied (p. 799). Louis Smith, in Stake (1995), added that a case study is "a bounded system" (p. 2). In other words, it exists on its own, which aids in defining the boundaries of the case. In this respect, this study focuses only on the perspectives of those IDs and administrators involved in the online course development process at the university.

\section{Research Participants, Setting, and Relationships}

This study focused on the perspectives of the IDs. The IDs play a crucial role both in the online course development experiences for many instructional faculty teaching online courses at the university and in supporting faculty on how best to integrate UDL strategies. Maxwell (2013) describes qualitative research as "focusing on specific situations or people, and emphasizing descriptions rather than numbers" (p. 30). Stake (1995) adds that the nature of qualitative research is for "promoting understanding" as opposed to explanation. Through a series of interviews and document reviews, the challenges impacting the integration of such practices at this institution were identified. Developing a better understanding of these challenges allows us to define strategies that would address potential gaps in services for SWDs.

Using purposeful and network selection (LeCompte, Preissie, \& Tesch, 1993), six individuals were selected to participate in semistructured interviews. The interviews focused on the participants' perspectives on the integration of UDL strategies into the online course 
development process. Four of the participants were IDs working for the ID Team, one participant was an assistant program manager in the DE Office, and the other was an ID in the College of Health and Human Sciences. According to LeCompte et al. (1993), network selection involves each successive participant or group being named by a previous set of participants. Interviews were first conducted with one of the senior IDs from the ID team and the assistant program manager for the DE Office. Both have played a critical role in advocating for the integration of such practices into the online course development process. To obtain a more in-depth understanding of the process at the university and the issues involved, each participant was asked to identify both colleagues that have been supportive and those that have been resistant (for one reason or another) to the incorporation of UDL strategies in online courses. To ensure anonymity, new participants were not made aware of how they were identified.

\section{Data Collection}

Qualitative data-gathering methods typically fall into three categories: observations, analysis of documents, and interviews (Banning, 1997). Two of these three methods were chosen for this study: semistructured interviews with each of the participants and document reviews of relevant source documents (i.e., DE Course Portfolio ratings sheets, OLC Scorecard feedback) from the DE Office).

Document analysis. In addition to semistructured interviews, document analysis was performed on the findings from the DE Course Portfolio ratings sheets (fall 2014 and spring 2015) and the OLC Scorecard feedback (see Appendix B for sample). These resources were covered at length in the introduction and informed the development of the interview protocol used in the six semistructured interviews (see Appendix D). Bowen (2009) states that document analysis involves skimming (superficial examination), reading (thorough examination), and interpretation, combining elements of both content analysis and thematic analysis. Content analysis is a method for classifying written or oral materials into identified categories (Hsieh \& Shannon, 2005), while thematic analysis emphasizes recurring patterns or themes within the data (Braun \& Clarke, 2006). Given the limited amount of data related to existing UDL strategies in the online course development process, no rubrics were used. The documents were skimmed to assess the current state of UDL strategies in the existing online course development models. These were used primarily to guide the development of the initial interview questions and triangulate the results of the semistructured interviews.

Semistructured interviews. Fontana and Frey (1998) define structured interviewing as a "situation in which an interviewer asks each respondent a series of pre-established questions with limited set of response categories." While useful for data collection and analysis purposes, it was desired that the interviews be more flexible and interactive. Semistructured interviews were desired, developing interview protocols that included open-ended questions about each participant's background, role at the university, role in the online course development process at the university, role in the integration of UDL strategies in online courses, perspectives on the integration of these strategies, and perspectives on faculty experiences addressing the integration of UDL strategies in their online courses. Appendix D elaborates on the specific questions that were asked.

Procedures. The initial participants, a senior ID from the ID Team and an assistant program manager with the DE Office, were directly solicited via phone. During the initial cold call, the purpose and scope of the study were explained, and each agreed to participate in the study. After the call, a follow-up email was sent with a copy of the informed consent form and a request 
for potential interview dates. Once the consent form was provided, several emails were exchanged to determine an agreed upon date.

The DE Office provided access to the DE Course Portfolio Reviews from fall 2014 and spring 2015, as well as the most recent OLC Scorecard review that the DE Office had submitted. Upon receipt, the documents were reviewed for UDL-related findings with the goal of using the findings to inform the development of the initial interview protocol. Prior to the interviews, several emails were exchanged with the assistant program manager to confirm the UDL-related information and verify the accuracy of the data.

The initial two interviews were conducted within four days of one another. The interviews were conducted online using an online webinar tool (i.e., Blackboard Collaborate). Interview sessions were recorded for transcription. Both interviews lasted approximately 60 minutes. After completing the initial interviews, recordings were outsourced to a web-based transcription company, which completed the transcripts within 72 hours. Upon receipt of the two transcripts, responses were summarized by question type (explained further below), and the researcher followed up via phone and/or email with participants to ensure that the summaries accurately reflected what they had conveyed. Maxwell (2013) referred to this as respondent validation, or the systematic solicitation of feedback about your data and conclusions from the people that you are studying.

At the conclusion of each interview, participants were asked to suggest another individual or set of individuals that could offer a well-rounded overview of the online course development process from the perspective of the IDs. Vogt (1999) describes this as snowball sampling, and it involves each research participant providing the name(s) of subsequent research participants. This continues until an adequate sample size is identified. In this study, the process was repeated until four additional participants had been identified. Data analysis (see below) was conducted after transcripts from Interviews 3 and 4 were created and, again, after Interviews 5 and 6 . Feedback from each round of interviews was re-integrated into the interview protocols as needed.

\section{Data Analysis}

Data was analyzed using constant comparative analysis (CCA; Corbin \& Strauss, 1990, p. 6). In CCA, data collection and data analysis go hand in hand. As soon as the data collection process starts, the data analysis starts as well. This is done because the analysis "is used to direct the next interview and observations" (Corbin \& Strauss, 1990, p. 6).

Due to time constraints, interviews were conducted in two-person blocks. For example, data from the first two interviews were transcribed and coded together before proceeding to the next set of interviews. This was done again after the third and fourth interviews. This adjustment to the methodology was more practical in that each subsequent block of interviews was more fruitful and targeted. By the end of the third and fourth interviews, themes were starting to emerge. This afforded follow-up with the initial participants.

To start, all interview transcripts and memos were converted to Microsoft Word documents and reformatted to 12-point Times New Roman font, lines were double-spaced, and line numbers were added to the entire transcript. Starting with the first interview transcript, responses were separated based upon the questions asked in the semistructured interviews. For example, for six questions, there would be six grouped responses. Next, each of those responses was open coded, specifically taking parts of the interviewee's direct quotes to create codes. This process was repeated with the other five interview transcripts. Next, all of the Question 1 open codes were merged into a separate Word document. This step was repeated for all of the remaining grouped 
open codes (i.e., Questions 2, 3, etc.). In open coding, events/actions/interactions are compared with others for similarities and differences (Corbin \& Strauss, 1990). By pooling the codes from each interview question, the researchers directly compared the feedback from each interview and advanced the data analysis process to the development of categories and subcategories. In this axial coding phase, codes were moved outside of the boundaries of the initial question categorization as needed. Final analysis resulted in the development of overarching themes. These are covered at length in the Results section.

In addition to CCA, a technique called summative content analysis (Hsieh \& Shannon, 2005) was used to assist with analyzing the findings. This technique starts with the quantification of certain words or content with the purpose of understanding the contextual use of the words or content (Hsieh \& Shannon, 2005). A slight modification was made to this technique by totaling the open codes that fit under the subcategories listed below. This allowed for the identification of the more predominant categories and themes for the purpose of reporting the results.

\section{Ensuring Validity}

Two strategies were employed to ensure worthiness of the data. Member checking reassures the accuracy of our participant's constructions and guards against researcher bias (Cho \& Trent, 2006; Maxwell, 2013). First, a series of semistructured interviews were conducted using CCA to analyze and code the transcripts. After receiving the transcripts from each round of interviews, participants were contacted to certify that what was written was in line with what they expressed during the interviews. This informed the refinement of the next interview protocol and the study's research questions, enabling researchers to focus more intently on themes identified from previous interviews. Triangulation was also used in this study. Cho and Trent (2006) stated that triangulation verifies and checks specific facts collected across data sources. The document reviews (i.e., DE Course Portfolio ratings, OLC Scorecard data) support findings derived from the interviews in that UDL strategies are not consistently integrated into the online course development process at the university. This provided the baseline context for the need for this study.

\section{Results and Discussion}

To enhance the meaningfulness and clarity of the analysis, both CCA and summative content analysis were integrated in the presentation of results. From this analysis, four major categories/themes emerged from the findings: ID/faculty partnerships, barriers to adoption, accommodation versus UDL, and other issues impacting the development of online courses (see Table 2). We will discuss each briefly. 


\section{Table 2}

Emerging Themes From Six Semistructured Interviews

\begin{tabular}{|c|c|c|c|}
\hline Categories & $\begin{array}{c}\text { Subcategories } \\
\text { (\# of codes in subcategory) }\end{array}$ & Sample Quotes & $\begin{array}{c}\text { Total \# } \\
\text { of Codes }\end{array}$ \\
\hline \multirow[t]{6}{*}{$\begin{array}{l}\text { ID/faculty } \\
\text { partnerships }\end{array}$} & \multirow[t]{2}{*}{$\begin{array}{l}\text { IDs and faculty have limited } \\
\text { time, resources, and } \\
\text { knowledge to properly } \\
\text { address accessibility (13) }\end{array}$} & $\begin{array}{l}\text { ID1 - "Faculty are very, very busy, over extended } \\
\text { and pulled in multiple directions. To ask them to } \\
\text { build effective online courses requires a } \\
\text { transformation of their teaching practice and it } \\
\text { seems to ask them to also understand and } \\
\text { implement UDL is just a bridge too far for most." }\end{array}$ & 39 \\
\hline & & $\begin{array}{l}\text { ID } 4 \text { - "I don't think that the expectation is that } \\
\text { every course that comes out is fully accessible or } \\
\text { fully compliant because we just don't have the } \\
\text { manpower to do that or the resources in place." }\end{array}$ & \\
\hline & \multirow[t]{2}{*}{$\begin{array}{l}\text { There are inconsistencies in } \\
\text { the way that each ID } \\
\text { approaches the integration of } \\
\text { UDL strategies with their } \\
\text { faculty (11) }\end{array}$} & $\begin{array}{l}\text { D2 - "Since I have beta-tested processes and } \\
\text { everything, I know what accessibility means and } \\
\text { exactly what is needed and why it is needed. } \\
\text { Other IDs don't have that experience and } \\
\text { therefore find it difficult to understand why you } \\
\text { ask for certain things." }\end{array}$ & \\
\hline & & $\begin{array}{l}\text { ID6 - "Because I've been having that, that } \\
\text { resistance from the faculty I haven't been pushing } \\
\text { things like make sure you use the header } \\
\text { functions in [MS] Word. I can't even get faculty } \\
\text { to use capitalization in [MS] Word. Headers? } \\
\text { Forget about it." }\end{array}$ & \\
\hline & $\begin{array}{l}\text { IDs fear overwhelming } \\
\text { faculty who are new to online } \\
\text { teaching (8) }\end{array}$ & $\begin{array}{l}\text { ID4 - "So we have these faculty members that } \\
\text { are already coming in and trying to learn this } \\
\text { whole new world of teaching and learning in } \\
\text { vernacular in concepts and technologies and then } \\
\text { when you compound that with legal concerns as } \\
\text { far as copyright goes, accessibility concerns } \\
\text { which also do have some [inaudible] occasions, } \\
\text { departmental concerns, accreditation concerns, all } \\
\text { of those types of things which really becomes } \\
\text { very overwhelming." }\end{array}$ & \\
\hline & $\begin{array}{l}\text { IDs often use different types } \\
\text { of communication (i.e., } \\
\text { couch their language, } \\
\text { present empirical data, } \\
\text { appeal to their morality) to } \\
\text { get faculty members to buy in } \\
\text { on including accessibility in } \\
\text { their course design (7) }\end{array}$ & $\begin{array}{l}\text { ID6 - "Couching it [UDL and accessibility] in } \\
\text { student success terms. Like the reason you want } \\
\text { to not have a two-hour long thing is because } \\
\text { people don't have the same attention span sitting } \\
\text { in front of the computer, and they will actually } \\
\text { listen to you more carefully if you can condense } \\
\text { your material." }\end{array}$ & \\
\hline
\end{tabular}




\section{Categories}

Barriers to adoption

\section{vs. UDL \\ Accommodation} VS. UDL

\section{Subcategories (\# of codes in subcategory)}

Factors impacting faculty adoption of UDL strategies:

- Low pay (1)

- Legal issues (2)

- Promotion and tenure (7)

- Ease (1)

- Lack of any academic or department mandates (17)

\section{Lack of administrative} enforcement when it comes to accessibility requirements (6)
Faculty exercise traditional approach to supporting students with disabilitiesi.e., medical model (15)

Faculty members are resistant to UDL and accessibility (6)

Many faculty members have never been asked to address UDL and accessibility (5)

IDs perspectives on accommodation vs. UDL (3)

\section{Sample Quotes}

ID2 - "[Accessibility] is a paradigm shift for many people, but this is the new reality. Everybody is going online and this is where the laws are going, so you really don't have a choice anymore."

ID3 - "In my opinion in some aspects it has to do with the promotion and tenure process. Faculty don't have to be so attentive to teaching per se, because when they are getting tenure, they're getting tenure based on their research and their grant. And teaching is like is part of the process, but it's not the most important part."

ID4 - "Faculty tend to follow the views of the administration or department."

ID6 - "Most departments will follow the lead of the accrediting agencies as to what they have to include [in an online course]."

ID5 - "Many faculty members initially think, 'well, I don't have any students who need accommodations/students with disabilities in my course... why do I need to do anything?"”

ID4 - "I don't want to just oversimplify but the problem that we've had in fact is when we do teach about accessibility, it scares many of them away... we don't want to make anyone feel like 'Oh, this student has special needs. I don't want them in the class."

ID5 - "Many faculty members just shut down when accessibility or UD-language [UDL] is used."

ID3 - "Many faculty members have never had to consider accessibility before. They are very open to it, but it is tough for some of them. Think about it... When you learned how to use Microsoft Word, PowerPoint, or any of these other applications, which are now second nature to most people, they didn't have to really consider making their work accessible. But now they really have to think about it because they have to provide instruction that is accessible to all of the students."

ID1 - "It would be cheaper and better for all involved to only change course when a need for accessibility is registered. Easier for one or two faculty to retrofit for accommodations, vs. making the hundreds of online courses accessible each semester. Online courses change more than you think."
Total \# of Codes

34 


\section{Categories}

Other issues impacting development of online courses

\section{Subcategories (\# of codes in subcategory)}

Many faculty members and academic units are resistant to the online course development process (8)

Many faculty members are
new to online teaching and
don't understand what is
involved in the process (4)

Sample Quotes

ID5 - "Faculty members feel like they should not have to focus on developing a course, more so on the content that is used in the course."

ID6 - "There's a shortage of qualified faculty to teach in some disciplines."

ID3 - "New online teaching faculty, ID Team staff, and DE Office staff coming to the university has resulted in greater buy-in."

ID6 - "A lot of faculty do not start using technology or do not make the decision to start using technology until a couple of weeks before the start of class."
Total \#

of Codes

12

ID/faculty partnerships. The importance of the ID/faculty relationship was very clearly defined throughout the interview process. Faculty members teaching online courses, in particular those coming to the ID team or the DE Office for support, rely heavily on IDs to provide guidance in the way of, for example, transitioning their face-to-face courses to online courses, assistance in choosing the correct educational technology to implement in their courses, and, in the context of these interviews, identifying ways to ensure that their course content is accessible to all students. Although some institutions have their IDs fully build out the courses and have the faculty members simply add content, that is not the case at this institution. Consequently, faculty members and IDs must work together to ensure the successful development of an online course.

During the interviews, it was evident that many of the IDs are very protective of this partnership. In other words, it was clear that inconsistencies exist among all of the participants when it comes to encouraging faculty members to integrate UDL strategies into their online courses. ID1 stated that members of the ID team have "varying levels of commitment to accessible design practices." Collectively, the IDs were concerned with overwhelming faculty members that are new to the online teaching experience. As ID1 added later, they have to "weigh their promotion against faculty situations where they barely have time to take on the basics of good online course design." As another ID put it, "Most faculty teaching online are novices" and are often unaware of the time commitment involved with preparing to teach online. As such, the IDs themselves struggle with getting faculty members to adhere to their own set of milestones, so some consider accessibility after the fact.

ID2 also added that many faculty members "don't know how to teach with technology." This, unfortunately, raises the bar for the successful integration of UDL strategies because it would suggest that faculty members would require a certain level of technical skill before they could or would take any initiative to ensure that their courses incorporate UDL or accessibility. ID6 summed it up best, signaling that due to resistance from the faculty, they "haven't been pushing things like make sure you use the header functions in [MS] Word. I can't even get faculty to use capitalization in [MS] Word. Headers? Forget about it."

Barriers to adoption. Interestingly, the barriers impacting the adoption of UDL strategies were numerous. The IDs, however, could only speculate as to what factors would improve adoption. Most of the comments centered on the external demands on faculty (i.e., other teaching and learning responsibilities), the lack of a top-down mandate to include UDL strategies, and faculty incentives (i.e., promotion and tenure). 
For example, many of the IDs mentioned that a good number of the faculty members teaching online courses are adjunct faculty. In many instances, these individuals may work other full-time jobs and do not receive the compensation (as compared to full-time instructors or teaching faculty), course-building time, and/or ID support required to successfully develop and integrate UDL or accessibility into their online courses.

Another factor mentioned was accreditation. Interestingly, this topic elicited discussion about enforcement and who could essentially "require" faculty to integrate accessible design practices in their online courses. ID4 commented that the DE Office and the ID team have essentially no ability to enforce these practices. It was suggested that this responsibility falls to the faculty member's department or possibly upper administration (e.g., the Provost's Office). ID6 supported this assertion, stating that "most departments will follow the lead of the accrediting agencies as to what they have to include [in an online course]."

The promotion and tenure process is an additional factor that is not often considered. ID3 remarked that "faculty don't have to be so attentive to teaching per se, because they are getting tenure based on their research and their grant. And teaching is part of the process, but it's not the most important part." Other IDs also suggested that the promotion and tenure process does not place a great deal of emphasis on teaching. For that reason, faculty members, specifically full-time research faculty who also have teaching responsibilities, may wonder why they should expend a great deal of resources in an area that they are not likely to be evaluated on.

Accommodation vs. UDL. This theme addresses the perceptions IDs have about how faculty respond to what is traditionally done to support students with disabilities in higher education (accommodation) versus proactively developing instructional content that is accessible to most students, regardless of disability (UDL strategies). ID5 stated that many faculty members initially think, "Well, I don't have a student with a disability in my course... why do I need to do anything?" Likewise, ID6 commented that "faculty members will only do something if the request comes from the top-down or from the Disability Services Office." Collectively, many of the IDs agreed that faculty are generally receptive to supporting a student with a disability if a direct request is made.

As it relates to integrating UDL strategies into an online course, the IDs appear to have differing opinions. One ID commented that

It would be cheaper and better for all involved to only change a course when a need for accessibility is registered. It is easier for one or two faculty members to retrofit for accommodations, versus making the hundreds of online courses accessible each semester. Online courses change more than you think.

On the other hand, some IDs stated that faculty members are actually quite open to considering UDL strategies; there is, however, some reluctance because they have "never been asked to do those kinds of things." ID4 affirmed this, commenting that accessibility "scares many of them away." Additional responses suggest that some of the reluctance may be more technical than personal. For example, a few of the IDs mentioned that some faculty members are limited when it comes to their understanding of how to make MS Word or PPT documents accessible. Therefore, the idea of having to learn these techniques while dealing with the other responsibilities of online course development may be a bit overwhelming.

Other issues impacting online course development. Some of the issues impacting the integration of UDL strategies in online courses have more to do with a general resistance to the 
adoption of online learning than anything else. A few of the IDs suggested that many faculty members lean toward how they learned best. ID4 stated it best:

There's an educational disposition to teach how we were taught. We were taught face-toface, we were taught via lecture, they sat in a chair and [expletive] they listened to that guy preach for three hours a day. So, you kids are going to sit down and you're going to listen to me, because that's how I learned and that's the way it works.

An additional concern of faculty appears to be the online delivery model for course content. Several IDs mentioned that faculty members feel they "should be discipline-focused" as opposed to concerning themselves with how a course is developed. In other words, the work of creating an online course shell and/or making instructional resources accessible should not be the responsibility of the faculty member. At some institutions, this work falls to the instructional designer, instructional technologist, or, in the case of integrating UDL strategies, an accessibility professional. As that is not the case at this university, it could be that faculty members and their respective academic departments are having to shift how they approach the learning process and how they integrate technology as well. As ID6 stated, “There's a shortage of qualified faculty to teach [online] in some disciplines. We have people who have just been hired in August to teach a new online course and they've never taught online before." Compound that with the fact that "some faculty do not start using technology or do not make the decision to start using technology until a couple of weeks before the start of class." Given the preparation involved in developing an online course (Herman, 2013), and the fact that many faculty members may not be comfortable teaching with technology (Ye, 2014), this paradigm shift in the learning process could be somewhat of a shock.

There are signs, however, that attitudes about teaching online are softening at the university. ID3 noted that faculty/staff turnover in the academic departments, the DE Office, and the ID Team has started to result in greater buy-in. In addition to that, as more academic units explore opportunities to transition some of their offerings online, there has been an increased emphasis on hiring faculty/instructors that are comfortable teaching online and teaching with technology.

\section{Limitations of This Study}

Three limitations emerged in this study: time, methodology, and researcher role. First, the time allotted was probably most impactful to the findings of this study. The projected timeline for actual data collection was unrealistic (6-8 weeks). Scheduling six interviews with little time to analyze the data between each interview (i.e., using CCA) was a shortsighted approach. The nature of this grounded theory method is to "build change, through process, into the method" (Corbin \& Strauss, 1990, p. 5). A great deal of time went into scheduling participants, interviewing them, accurately transcribing 60-plus-minute interviews, and then following up with the participants to ensure the accuracy of responses. A more constructive approach would have been to build as much time into the data analysis part of the process as was dedicated to the data collection process. This would have resulted in more time to process the findings. Adding to this issue was the choice to use the summative content analysis technique. Hsieh and Shannon (2005) argue that this type of technique relies on credibility and, as such, it is suggested that researchers check with their participants to ensure that the themes identified are in line with their responses. Given the time constraints detailed previously, it would have been preferable to have more time for additional follow up with the study's participants.

Finally, researcher role was a factor as well. Pseudonyms were used sparingly in the presentation of the results and discussion. This was done in an attempt to eliminate potential 
indicators as much as possible. The reason for this was that the researchers are employed at this institution and work very closely with the participants involved. The small size of that office makes identification fairly easy. As such, generalizing the findings as much as possible eliminates any potentially embarrassing situations for those that were gracious enough to participate in this study.

\section{Conclusion}

Our findings revealed a number of factors causing instructional faculty to reject the integration of UDL strategies in their online courses. There was very little evidence, however, of strategies that were implemented to improve adoption. Despite this, the IDs did highlight strategies that may aid in improving faculty buy-in with respect to integrating UDL strategies into online courses developed at the university. According to several participants, these techniques have been successful in "disarming" the resistance that many faculty members have toward the inclusion of UDL strategies. They are as follows:

1. Provide a consistent approach toward the integration of UDL strategies in online courses;

2. UDL strategies employed in online courses should be more prescriptive; and,

3. the focus should be on UDL strategies, not adding accessibility.

As described previously, the ID/faculty partnership is a critical part of a successful online course at the university. As it relates to the integration of UDL strategies, it is imperative that all of the IDs have the same approach toward this aspect of the online course development process. Existing practices show clear differences in how IDs approach the integration of UDL strategies and, as such, this is evident not only in the reflections of those IDs being interviewed, but also in the document review findings.

Another strategy employed by some of the IDs to promote the integration of UDL strategies involves streamlining the number of things to be considered by faculty and embedding those techniques throughout the online course development process. ID2 described how this was handled in the past, where faculty members would be guided through the entire design and development process, and then the last thing that was covered was how to make the course content accessible. As ID2 put it, "[Faculty members] were looking at me like, you've got to be kidding! This is too much! After all that I've done, I still have to do this?" ID4 echoed the new strategy best, stating that they "try very hard to boil it down to three, four, or five core things that faculty members can do, that are super easy, that can make their course accessible to probably $90-95 \%$ of the folks out there." This sentiment was shared by other IDs commenting that faculty members are willing to adopt such practices if they are easy to do and if they are made aware of inclusive design techniques during the development process as opposed to at the end.

To encourage faculty to integrate UDL strategies in their online courses, some of the IDs cajole faculty by appealing to the trusting nature of the ID/faculty partnership, the faculty member's sense of "doing the right thing," or actually presenting empirical data from the research. Others, however, back away from using UDL-specific language altogether. For example, "couching one's language" was frequently mentioned during the interviews. ID5 stated that they often "avoid using terms like accessibility or $U D L$ " because those terms tend to be off-putting to faculty members. ID6 suggested it was best to "couch [UDL strategies] in student success terms." Encouraging faculty members to think 'will this actually improve student learning' or 'could this possibly impact my evaluations if I do this as a service to the students?' For example, choosing to 
use a series of short, 15-minute video clips as opposed to an entire 2-hour video or adding knowledge checks throughout a lesson as opposed to none at all are, as perceived by the IDs, more positively perceived by students. This strategy of shifting the focus to inclusive design choices as opposed to choices around disability tended to, in their collective opinions, disarm faculty members, allowing for a more fruitful and collaborative partnership.

Though not focused on UDL strategies, Herman (2013) explored faculty incentives and compensation for online course delivery and development to determine the frequency and types of incentives that were well received by faculty. He discovered that the retention of intellectual property rights, financial compensation, and teaching/technology grants and awards were three of the most commonly offered incentives among the institutions participating in the study. This suggests that, with respect to improving the adoption of UDL strategies, higher education institutions must also consider the types of incentives that would not only promote adoption by faculty but also sustain it. 


\section{References}

Aguirre, R. T. P., \& Duncan, C. (2013). Being an elbow: A phenomenological authoethonography of faculty-student collaboration for accommodations. Journal of Teaching in Social Work, 33, 531-551. https://doi.org/10.1080/08841233.2013.827611

Baker, T. E., Cimini, J. F., \& Cleveland, C. T. (2011). The mock trial journey: An assessment. Forensic Examiner, 20, 32-43.

Banning, J. H. (1997). Assessing the campus' ethical climate: A multidimensional approach. New Directions for Student Services, 1997, 95-105. https://doi.org/10.1002/ss.7706

Bongey, S. B., Cizadlo, G., \& Kalnbach, L. (2010). Blended solutions: Using a supplemental online course site to deliver UDL. Campus - Wide Information Systems, 27, 4-16. https://doi.org/10.1108/10650741011011246

Braun, V., \& Clarke, V. (2006). Using thematic analysis in psychology. Qualitative Research in Psychology, 3, 77-101. https://doi.org/10.1191/1478088706qp063oa

Burgstahler, S. (2007). Accessibility training for distance learning personnel. Retrieved from https://athenpro.org/node/41

Burgstahler, S. (2011). Universal design: Implications for computing education. Transactions on Computing Education, 11, 1-17.

Burgstahler, S. (2012). Equal access: Universal design of distance learning (pp. 1-4). University of Washington, DO-IT. Retrieved from http://www.uvm.edu/ cdci/employees/files/UDLofdistancelearning.pdf

CAST. (2011). Universal design for learning guidelines version 2.0. Wakefield, MA: Author. Retrieved from http://udlguidelines.cast.org/binaries/content/assets/udlguidelines/udlgv2-0/udlg fulltext v2-0.doc

Catalano, A. (2014). Improving distance education for students with special needs: A qualitative study of students' experiences with an online library research course. Journal of Library \& Information Services, 8, 17-31. https://doi.org/10.1080/1533290X.2014.902416

Cho, J., \& Trent, A. (2006). Validity in qualitative research revisited. Qualitative Research, 6, 319-340. https://doi.org/10.1177/1468794106065006

Chodock, T., \& Dolinger, E. (2009). Applying universal design to information literacy: Teaching students who learn differently at Landmark College. Reference \& User Services Quarterly, 49, 24-32. https://doi.org/10.5860/rusq.49n1.24

Corbin, J., \& Strauss, A. (1990). Basics of qualitative research: Grounded theory procedures and techniques. Basics of Qualitative Research: Grounded Theory Procedures and Techniques, 41.

Dallas, B. K., Upton, T. D., \& Sprong, M. E. (2014). Postsecondary faculty attitudes toward inclusive teaching strategies. Journal of Rehabilitation, 80, 12-20.

Davies, P. L., Schelly, C. L., Spooner, C. L., \& University, C. S. (2013). Measuring the effectiveness of universal design for learning intervention in postsecondary education. Journal of Postsecondary Education \& Disability, 26, 195-220. 
Dotger, S. (2011). Exploring new territories: My trajectory toward becoming an inclusive science teacher educator. Reflective Practice, 12, 415-426. https://doi.org/10.1080/14623943.2011.571871

Dy, C. L. (2005). Faculty knowledge about disability laws and their attitudes toward students with disabilities at Northern Virginia Community College (D.A.). George Mason University, Ann Arbor. Retrieved from http://search.proquest.com/docview/305364768?accountid=14541

Fontana, A., \& Frey, J. H. (1998). Interviewing. In N. K. Denzin \& Y. S. Lincoln, Collecting and interpreting qualitative materials (pp. 47-78). Thousand Oaks, CA: SAGE Publications.

Grabinger, R. S., Aplin, C., \& Ponnappa-Brenner, G. (2008). Supporting learners with cognitive impairments in online environments. TechTrends, 52, 63-69.

Gradel, K., \& Edson, A. J. (2009). Putting universal design for learning on the higher ed agenda. Journal of Educational Technology Systems, 38, 111-121. https://doi.org/10.2190/ET.38.2.d

Habib, L., Berget, G., Sandnes, F. E., Sanderson, N., Kahn, P., Fagernes, S., \& Olcay, A. (2012). Dyslexic students in higher education and virtual learning environments: An exploratory study. Journal of Computer Assisted Learning, 28, 574-584.

Herman, J. (2013). Faculty incentives for online course design, delivery, and professional development. Innovative Higher Education, 38, 397-410. https://doi.org/10.1007/s10755$\underline{012-9248-6}$

Higbee, J. L., \& Goff, E. (2008). Pedagogy and student services for institutional transformation: Implementing universal design in higher education. Center for Research on Developmental Education and Urban Literacy. Retrieved from http://eric.ed.gov/?id=ED503835

Hong, B. S. S., \& Himmel, J. (2009). Faculty attitudes and perceptions toward college students with disabilities. College Quarterly, 12, 6-6.

Hsieh, H.-F., \& Shannon, S. E. (2005). Three approaches to qualitative content analysis. Qualitative Health Research, 15, 1277-1288. https://doi.org/10.1177/1049732305276687

Izzo, M. V., Murray, A., \& Novak, J. (2008). The faculty perspective on universal design for learning. Journal of Postsecondary Education and Disability, 21, 60-72.

Kumar, K. (2010). A journey towards creating an inclusive classroom: How universal design for learning has transformed my teaching. Transformative Dialogues: Teaching \& Learning Journal [Serial Online]. November, 4, 1-5.

Kumar, K. L., \& Wideman, M. (2014). Accessible by design: Applying UDL principles in a first year undergraduate course. Canadian Journal of Higher Education, 44, 125-147.

LeCompte, M. D., Preissie, J., \& Tesch, R. (1993). Selecting and sampling in qualitative research. In Ethnography and qualitative design in educational research (2nd ed., pp. 56-85). San Diego, CA: Academic Press.

Lombardi, A. R., Murray, C., \& Gerdes, H. (2011). College faculty and inclusive instruction: Self-reported attitudes and actions pertaining to Universal Design. Journal of Diversity in Higher Education, 4, 250-261. https://doi.org/10.1037/a0024961 
Integrating UDL Strategies Into the Online Course Development Process: Instructional Designers' Perspectives

Maxwell, J. A. (2013). Qualitative research design: An interactive approach. Thousand Oaks, CA: SAGE Publications.

McGuire, J. M., \& Scott, S. S. (2006). Universal Design for Instruction: Extending the universal design paradigm to college instruction. Journal of Postsecondary Education \& Disability, $19,124-134$.

Mcguire, J. M., Scott, S. S., \& Shaw, S. F. (2003). Universal Design for Instruction: The paradigm, its principles, and products for enhancing instructional access. Journal of Postsecondary Education \& Disability, 17, 11-21.

Moon, N. W., Utschig, T. T., Todd, R. L., \& Bozzorg, A. (2011). Evaluation of programmatic interventions to improve postsecondary STEM education for students with disabilities: Findings from SciTrain University. Journal of Postsecondary Education and Disability, 24, 331-349.

Moriarty, M. A. (2007). Inclusive pedagogy: Teaching methodologies to reach diverse learners in science instruction. Equity \& Excellence in Education, 40, 252-265. https://doi.org/10.1080/10665680701434353

Nielsen, D. (2013). Universal design in first-year composition-Why do we need it, how can we do it? The CEA Forum, 42, 3-29.

Ragpot, L. (2011). Assessing student learning by way of drama and visual art: A semiotic mix in a course on cognitive development. Education as Change, 15, S63-S78. https://doi.org/10.1080/16823206.2011.643625

Rao, K., \& Tanners, A. (2011). Curb cuts in cyberspace: Universal instructional design for online courses. Journal of Postsecondary Education \& Disability, 24, 211-229.

Rao, S. (2004). Faculty attitudes and students with disabilities in higher education: A literature review. College Student Journal, 38, 191-198.

Rose, D. H., \& Gravel, J. W. (2012). Curricular opportunities in the digital age. Jobs for the Future, 1-29.

Ruddin, L. P. (2006). You can generalize stupid! Social scientists, Bent Flyvbjerg, and case study methodology. Qualitative Inquiry, 12, 797-812.

https://doi.org/10.1177/1077800406288622

Schelly, C. L., Davies, P. L., \& Spooner, C. L. (2011). Student perceptions of faculty implementation of universal design for learning. Journal of Postsecondary Education and Disability, 24, 17-30.

Seok, S., DaCosta, B., Kinsell, C., \& Tung, C. K. (2010). Comparison of instructors' and students' perceptions of the effectiveness of online courses. Quarterly Review of Distance Education, 11, 25-36.

Silver, P., Bourke, A., \& Strehorn, K. C. (1998). Universal instructional design in higher education: An approach for inclusion. Equity \& Excellence in Education, 31, 47-51. https://doi.org/10.1080/1066568980310206

Simoncelli, A., \& Hinson, J. M. (2008). College students' with learning disabilities personal reactions to online learning. Journal of College Reading and Learning, 38, 49-62. https://doi.org/10.1080/10790195.2008.10850308 
Smith, F. G. (2012). Analyzing a college course that adheres to the universal design for learning (UDL) framework. Journal of the Scholarship of Teaching \& Learning, 12, 31-61.

Stake, R. (1995). The art of case study research. Thousand Oaks, CA: SAGE Publications.

The Center for Universal Design - Universal Design Principles. (n.d.). Retrieved from http://www.ncsu.edu/ncsu/design/cud/about_ud/udprinciplestext.htm

Vajoczki, S., Watt, S., Fenton, N., Tarkowski, J., Voros, G., \& Vine, M. M. (2014). Lecture capture: An effective tool for universal instructional design? Canadian Journal of Higher Education, 44, 1-29.

Vogt, W. P. (1999). Dictionary of statistics and methodology: A non-technical guide for the social sciences. London: Sage Publications.

Yang, C.-H., Tzuo, P.-W., \& Komara, C. (2011). WebQuests and collaborative learning in teacher preparation: A Singapore study. Educational Media International, 48, 209-220. https://doi.org/10.1080/09523987.2011.607325

Ye, H. (2014). Universal design for learning in an online teacher education course: Enhancing learners' confidence to teach online. MERLOT Journal of Online Learning and Teaching 10(2), 283-298. Retrieved from http://jolt.merlot.org/vol10no2/he_0614.pdf 
Integrating UDL Strategies Into the Online Course Development Process: Instructional Designers' Perspectives

Appendix A

Inclusive Teaching Strategies Inventory: Subscales, Items, and Response Stems

\begin{tabular}{|c|c|}
\hline Response Stem & $\begin{array}{l}\text { Attitudes: I believe it's important to... } \\
\text { Actions: I do... }\end{array}$ \\
\hline Subscale & Item \\
\hline \multirow[t]{8}{*}{ Accommodations } & $\begin{array}{l}\text { allow students with documented disabilities to use technology (e.g., } \\
\text { laptop, calculator, spellchecker) to complete tests even when such } \\
\text { technologies are not permitted for use by students without } \\
\text { disabilities }\end{array}$ \\
\hline & $\begin{array}{l}\text { provide copies of my lecture notes or outlines to students with } \\
\text { documented disabilities }\end{array}$ \\
\hline & $\begin{array}{l}\text { provide copies of my overhead and/or PowerPoint presentations to } \\
\text { students with documented disabilities }\end{array}$ \\
\hline & $\begin{array}{l}\text { allow flexible response options on exams (e.g., change from written } \\
\text { to oral) for students with documented disabilities }\end{array}$ \\
\hline & $\begin{array}{l}\text { allow students with documented disabilities to digitally record } \\
\text { (audio or visual) class sessions }\end{array}$ \\
\hline & $\begin{array}{l}\text { make individual accommodations for students who have disclosed } \\
\text { their disability to me }\end{array}$ \\
\hline & $\begin{array}{l}\text { arrange extended time on exams for students who have documented } \\
\text { disabilities }\end{array}$ \\
\hline & $\begin{array}{l}\text { extend the due dates of assignments to accommodate the needs of } \\
\text { students with documented disabilities }\end{array}$ \\
\hline \multirow[t]{4}{*}{ Accessible Course Materials } & use a course website (e.g., Blackboard or faculty web page) \\
\hline & $\begin{array}{l}\text { put my lecture notes online for ALL students (on Blackboard or } \\
\text { another website) }\end{array}$ \\
\hline & post electronic versions of course handouts \\
\hline & $\begin{array}{l}\text { allow students flexibility in submitting assignments electronically } \\
\text { (e.g., mail attachment, digital drop box) }\end{array}$ \\
\hline \multirow[t]{4}{*}{ Course Modifications } & $\begin{array}{l}\text { allow a student with a documented disability to complete extra } \\
\text { credit assignments }\end{array}$ \\
\hline & $\begin{array}{l}\text { reduce the overall course reading load for a student with } \\
\text { documented disability even when I would not allow a reduced } \\
\text { reading load for another student }\end{array}$ \\
\hline & $\begin{array}{l}\text { reduce the course reading load for ANY student who expresses a } \\
\text { need }\end{array}$ \\
\hline & $\begin{array}{l}\text { allow ANY student to complete extra credit assignments in my } \\
\text { course(s) }\end{array}$ \\
\hline \multirow[t]{4}{*}{ Inclusive Lecture Strategies } & $\begin{array}{l}\text { repeat the question back to the class before answering when a } \\
\text { question is asked during a class session }\end{array}$ \\
\hline & $\begin{array}{l}\text { begin each class session with an outline/agenda of the topics that } \\
\text { will be covered }\end{array}$ \\
\hline & summarize key points throughout each class session \\
\hline & $\begin{array}{l}\text { connect key points with larger course objectives during class } \\
\text { sessions }\end{array}$ \\
\hline
\end{tabular}


Integrating UDL Strategies Into the Online Course Development Process: Instructional Designers' Perspectives

\begin{tabular}{|c|c|}
\hline \multirow[t]{9}{*}{ Inclusive Classroom } & $\begin{array}{l}\text { use technology so that my course material can be available in a } \\
\text { variety of formats (e.g., podcast of lecture available for download, } \\
\text { course readings available as mp3 files) }\end{array}$ \\
\hline & $\begin{array}{l}\text { use interactive technology to facilitate class communication and } \\
\text { participation (e.g., Discussion Board) }\end{array}$ \\
\hline & $\begin{array}{l}\text { present course information in multiple formats (e.g., lecture, text, } \\
\text { graphics, audio, video, hands-on exercises) }\end{array}$ \\
\hline & create multiple opportunities for engagement \\
\hline & survey my classroom in advance to anticipate any physical barriers \\
\hline & $\begin{array}{l}\text { include a statement in my syllabus inviting students with } \\
\text { disabilities to discuss their needs with me }\end{array}$ \\
\hline & $\begin{array}{l}\text { make a verbal statement in class inviting students with disabilities } \\
\text { to discuss their needs with me }\end{array}$ \\
\hline & $\begin{array}{l}\text { use a variety of instructional formats in addition to lecture, such as } \\
\text { small groups, peer-assisted learning, and hands-on activities }\end{array}$ \\
\hline & $\begin{array}{l}\text { supplement class sessions and reading assignments with visual aids } \\
\text { (e.g., photographs, videos, diagrams, interactive simulations) }\end{array}$ \\
\hline \multirow[t]{4}{*}{ Inclusive Assessment } & $\begin{array}{l}\text { allow students to demonstrate the knowledge and skills in ways } \\
\text { other than traditional tests and exams (e.g., written essays, } \\
\text { portfolios, journals) }\end{array}$ \\
\hline & allow students to express comprehension in multiple ways \\
\hline & $\begin{array}{l}\text { be flexible with assignment deadlines in my course(s) for ANY } \\
\text { student who expresses a need }\end{array}$ \\
\hline & $\begin{array}{l}\text { allow flexible response options on exams (e.g., change from written } \\
\text { to oral) for ANY student who expresses a need }\end{array}$ \\
\hline Response stem & I am confident in... \\
\hline \multirow[t]{6}{*}{ Disability Law \& Concepts } & my understanding of the Americans with Disabilities Act (1990) \\
\hline & $\begin{array}{l}\text { my responsibilities as an instructor to provide or facilitate } \\
\text { disability-related accommodations }\end{array}$ \\
\hline & $\begin{array}{l}\text { my knowledge to make adequate accommodations for students with } \\
\text { disabilities in my course(s) }\end{array}$ \\
\hline & my understanding of section 504 of the Rehabilitation Act of 1973 \\
\hline & my understanding of Universal Design \\
\hline & my understanding of the legal definition of disability \\
\hline Response stem & I know... \\
\hline \multirow[t]{4}{*}{ Campus Resources } & a Disability Services office exists on this campus \\
\hline & $\begin{array}{l}\text { what type of services are provided by the Disability Services office } \\
\text { on this campus }\end{array}$ \\
\hline & $\begin{array}{l}\text { students with documented disabilities on this campus receive } \\
\text { adequate services from the Disability Services Office }\end{array}$ \\
\hline & $\begin{array}{l}\text { where I can find additional support at this university when students } \\
\text { with disabilities are having difficulties in my course }\end{array}$ \\
\hline
\end{tabular}




\section{Appendix B}

\section{OLC Scorecard [Sample]}

\section{Quality Scorecard for the Administration of Online Programs}

\section{$\mathbf{0}=$ Deficient $\quad \mathbf{1}$ = Developing $\quad \mathbf{2}=$ Accomplished $\quad 3$ = Exemplary}

\section{INSTITUTIONAL SUPPORT (27 POINTS)}

SCORE

1 The institution has a governance structure to enable clear, effective, and comprehensive decision making related to online education.

2 The institution has policy and guidelines that confirm a student who registers in an online course or program is the same student who participates in and completes the course or program and receives academic credit. This is done by verifying the identity of a student by using methods such as (a) a secure login and passcode, (b) proctored examinations, or (c) other technologies and practices that are effective in verifying student identity.

3 The institution has a policy for intellectual property of course materials; it specifically addresses online course materials and is publicly visible online.

4 The institution has defined the strategic value of online learning to its enterprise and stakeholders.

5 The organizational structure of the online program supports the institution's mission, values, and strategic plan.

6 The online program's strategic plan is reviewed for its continuing relevance, and periodically improved and updated.

7 The institution has a process for planning and allocating resources for the online program, including financial resources, in accordance with strategic planning.

8 The institution demonstrates sufficient resource allocation, including financial resources, in order to effectively support the mission of online education.

9 The institution has a governance structure to enable systematic and continuous improvement related to the administration of online education.

TECHNOLOGY SUPPORT (21 POINTS)

1 A documented technology plan that includes electronic security measures (e.g., password protection, encryption, secure online or proctored exams, etc.) is in place and operational to ensure quality, in accordance with established standards and regulatory requirements.*

Note: The order of quality indicators within each category does not signify rank of importance.

They are provided in random order.

ULC ONLINE LEARNING 


\section{Appendix C}

\section{6-Week Readiness Review}

\begin{tabular}{|c|c|c|}
\hline Main Section & Subsection & Original Checklist Items \\
\hline \multirow[t]{12}{*}{ Syllabus } & \multirow[t]{6}{*}{ Basic Information } & $\begin{array}{l}\text { Instructor Information (name, contact information-preferred } \\
\text { and alternate) }\end{array}$ \\
\hline & & Office Hours (online and/or in-person office hours) \\
\hline & & $\begin{array}{l}\text { Basic Course Information (course number/section, title, credit } \\
\text { hours) }\end{array}$ \\
\hline & & $\begin{array}{l}\text { Nature of Course Delivery (asynchronous, synchronous, } \\
\text { required face-to-face meetings/exams) }\end{array}$ \\
\hline & & Blackboard Login Instructions \\
\hline & & E-reserve Instructions, if applicable \\
\hline & \multirow[t]{5}{*}{ About the Course } & Course Description (about the course/subject, prerequisites, etc.) \\
\hline & & Required Textbooks \\
\hline & & Course Learning Objectives/Outcomes \\
\hline & & $\begin{array}{l}\text { Gen Ed Learning Outcomes or Program Learning Outcomes, if } \\
\text { applicable }\end{array}$ \\
\hline & & Technology Requirements \\
\hline & Course Schedule & $\begin{array}{l}\text { Weekly Course Schedule presented in a tabular format (includes } \\
\text { units/modules with start and end dates, delivery mode if in } \\
\text { hybrid course, readings, assignments, due dates, point values) }\end{array}$ \\
\hline
\end{tabular}

\begin{tabular}{ll}
\hline $\begin{array}{l}\text { Assignments and } \\
\text { Grading }\end{array}$ & $\begin{array}{l}\text { Assignment Description (due dates, requirements/expectations, } \\
\text { criteria for grading/rubrics, points and/or percentages) }\end{array}$ \\
\cline { 2 - 2 } & Grading Scale \\
\cline { 2 - 2 } & Attendance and Participation Requirements (if applicable) \\
\hline $\begin{array}{l}\text { Course Policies (late work, make-up exams, extra credit, } \\
\text { incompletes, etc.) }\end{array}$ \\
$\begin{array}{ll}\text { Additional Course } \\
\text { Resources }\end{array}$ & $\begin{array}{l}\text { Recommended Course Resources (readings, tutorials, external } \\
\text { websites, exhibitions, field trips, multimedia resources, etc.), if } \\
\text { applicable }\end{array}$ \\
\hline
\end{tabular}




\begin{tabular}{|c|c|c|}
\hline & \multirow{6}{*}{$\begin{array}{l}\text { University } \\
\text { Requirements }\end{array}$} & Academic Integrity \\
\hline & & Disability Accommodations \\
\hline & & Diversity, Religious Holidays, etc. \\
\hline & & Student Privacy \\
\hline & & Student Responsibilities \\
\hline & & Student Services (Library, Writing Center, Counseling, etc.) \\
\hline \multirow{12}{*}{$\begin{array}{l}\text { Course } \\
\text { Navigation } \\
\text { and } \\
\text { Presentation }\end{array}$} & Home Page & $\begin{array}{l}\text { Course has a well-designed landing page (may include course } \\
\text { visuals, announcements, to-do list or what's due) }\end{array}$ \\
\hline & Announcements & $\begin{array}{l}\text { Weekly Announcement has been set up, either on the Home } \\
\text { Page or a separate page. }\end{array}$ \\
\hline & Course Welcome & $\begin{array}{l}\text { Includes a warm welcome message to students (audio, video, } \\
\text { and/or text based) }\end{array}$ \\
\hline & & Includes clear instructions for getting started \\
\hline & Syllabus & $\begin{array}{l}\text { Syllabus can be navigated easily (e.g., consistent use of headers } \\
\text { or styles in Word document, PDF file with bookmarks, etc.) }\end{array}$ \\
\hline & & Print version of syllabus available \\
\hline & Weekly Units & $\begin{array}{l}\text { Separate units for each week (or a specified time period) with } \\
\text { specific dates }\end{array}$ \\
\hline & & $\begin{array}{l}\text { Units having consistent structure (e.g., introduction to the topic, } \\
\text { learning objectives, readings, mini-lectures, labs, assignments } \\
\text { including how/where students will participate or submit, } \\
\text { discussions, etc.). }\end{array}$ \\
\hline & & $\begin{array}{l}\text { Links to recorded lectures/presentations are provided and } \\
\text { working }\end{array}$ \\
\hline & & Link to external websites, e-books, YouTube, etc. are working \\
\hline & & $\begin{array}{l}\text { Includes all graded and nongraded assignments for the week. } \\
\text { Graded assignments should include associated grading } \\
\text { criteria/rubrics }\end{array}$ \\
\hline & & $\begin{array}{l}60 \% \text { of the course content is completed }(100 \% \text { of course to be } \\
\text { completed one week before the semester starts) }\end{array}$ \\
\hline
\end{tabular}




\begin{tabular}{|c|c|c|}
\hline & $\begin{array}{l}\text { Online } \\
\text { Discussions }\end{array}$ & $\begin{array}{l}\text { Discussion/Blog/Journal prompts and descriptions have been } \\
\text { created in Blackboard }\end{array}$ \\
\hline & Course Tools & $\begin{array}{l}\text { Available to students as applicable for the course (e.g., } \\
\text { MyGrades, Email, Collaborate, Blog, SafeAssign, etc.) }\end{array}$ \\
\hline & \multirow[t]{2}{*}{ Student Resources } & $\begin{array}{l}\text { Includes links to Student Responsibilities and Services modules } \\
\text { pages }\end{array}$ \\
\hline & & Includes access to Blackboard Help/FAQs \\
\hline & $\begin{array}{l}\text { Tests/Quizzes (if } \\
\text { applicable) }\end{array}$ & Tests/Quizzes are developed in Blackboard with assigned points \\
\hline \multirow[t]{5}{*}{ Accessibility } & Video & All videos are captioned or have transcripts \\
\hline & PPT & $\begin{array}{l}\text { Accessible PowerPoint slides are available for each } \\
\text { lecture/presentation with videos }\end{array}$ \\
\hline & Word & All Word documents are accessible \\
\hline & PDF & All PDF documents are text based and fully accessible \\
\hline & $\begin{array}{l}\text { External } \\
\text { Resources }\end{array}$ & $\begin{array}{l}\text { All publisher-provided resources are accessible, or alternative } \\
\text { equivalent resources or strategies are provided }\end{array}$ \\
\hline
\end{tabular}


Integrating UDL Strategies Into the Online Course Development Process: Instructional Designers' Perspectives

\section{Appendix D}

\section{Interview Guide}

\section{Research Question(s):}

1. What perceptions do online course developers (i.e., DE Office, ID Team, IDs and instructional faculty within colleges and schools) at the university have about incorporating UDL strategies into the online course development process?

a. How do online course developers at the university define "UDL strategies"?

b. What factors do online course developers perceive as impacting the adoption/rejection of UDL strategies by instructional faculty teaching online courses at the university?

\section{Potential Interview Questions:}

- $\quad$ Tell me a little about yourself....

- Name? How long have you worked at the university? What office do you work in? How long have you been in that office?

\section{Exploration Question(s)...}

- Describe the online course development process(es) at the university.

- In your opinion, what are the pros and cons of the existing processes?

- What is your role in the online course development process?

○ Instructional faculty? Instructional designer? Decision-maker? Student?

\section{Engagement Questions}

- If I ask you to make your course accessible, what does that mean to you?

Follow up questions... How do you define accessibility? Is your definition centered on access for a SWD or just the online student in general? Does the definition matter? UDL vs. accessible design practices?

- "UDL strategies (i.e., captions, alt text, etc.)..." is the lowest rated item on the DE Office's Course Portfolio ratings reviews (Fall 2014, Spring 2015). Why do you think that is?

Follow up questions...Are the issues training-specific? Process-specific? Issues with the definitions? Issues with what is being asked?

- What, in your opinion, causes online course developers at the university to implement/not implement these practices?

Follow up questions... What are the barriers to/drivers of adoption for instructional faculty? What are the barriers to/drivers of adoption for instructional designers? What are the barriers to/drivers of adoption for the DE Office? Academic Units? What advantages/disadvantages do you see in adopting these practices? What, in your opinion, would incentivize instructional faculty to integrate UDL principles and practices into the online course development process at the university?

- In your opinion, what perceptions do instructional faculty members have as it relates to supporting a student with a disability in an online course?

\section{Exit Question}

- Is there anything else you would like to add about faculty adoption/rejection of UDL strategies based upon UDL? 